www.periodicos.unimontes.br/index.php/caminhosdahistoria

\title{
A CONSTRUÇÃO DO ETHOS DE TORCEDOR NA CIDADE MODERNA: “A RAINHA DOS SPORTS, OS SURURUS E A VICTORIA QUE O SOL NÃO VIU”-
} (1926-1930)

\author{
Georgino Jorge de Souza Neto ${ }^{1}$
}

Recebido em: 23/02/2020

Aprovado em: 20/04/2020

Resumo: O presente artigo tencionou elaborar uma representação da construção da identidade torcedora na cidade de Belo Horizonte-MG, na segunda metade da década de 1920, momento em que o cenário futebolístico se altera a partir da perda do protagonismo do América-MG e da ascensão do Clube Atlético Mineiro e do Palestra Itália, o que reconfigura as disputas e consequentemente o desenho dos modos de torcer, instituindo um campo mais precisamente demarcado do pertencimento clubístico na cidade. Neste sentido, buscamos como fonte privilegiada de investigação os periódicos locais, que descreviam o cotidiano esportivo/futebolístico belorizontino, reverberando os acontecimentos elegidos como mais significativos. A partir da narrativa periódica foi possível estabelecer um panorama sobre os torcedores e seus comportamentos mais tipificados, atrelados à lógica do consumo e da identidade, ilustrados por episódios como concursos de torcedoras, aumento da violência (e por conseguinte da tentativa de controle sobre os modos de torcer) e a inauguração de novos e adequados espaços, os estádios de futebol.

Palavras-chave: Futebol; História do esporte; Modernidade; Torcer; Belo Horizonte - MG.

Abstract: The present article intended to elaborate a representation of the construction of the fan identity in the city of Belo Horizonte-MG, in the second half of the 1920s, a moment when the football scene changes from the loss of the protagonism of América-MG and the rise of the Clube Atlético Mineiro and Palestra Itália, which reconfigures the disputes and consequently the design of the ways of cheering, establishing a more precisely marked field of club membership in the city. In this sense, we sought as a privileged source of investigation the local newspapers, which described the daily sports / football in Belo Horizonte, reverberating the events chosen as more significant. From the periodic narrative it was possible to establish an overview of the fans and their more typified behaviors, linked to the logic of consumption and identity, illustrated by episodes such as fan contests, increased violence (and therefore the attempt to control the ways to cheer) and the opening of new and suitable spaces, the football stadiums.

Keywords: Football; Sport History; Modernity; Football Fans; Belo Horizonte - MG.

Resumen: El presente artículo presentó la intención de elaborar una representación de la construcción de la identidad de hinchas de fútbol en la ciudad de Belo Horizonte-MG, en la segunda mitad de la década de 1920, un momento en el que la escena del fútbol cambia por la

\footnotetext{
${ }^{1}$ Doutor em Estudos do lazer, Professor do Departamento de Educação Física e Desporto da Universidade Estadual de Montes Claros-MG, Brasil. E-mail: netogeorgino@gmail.com. ORCID: https://orcid.org/0000-00029375-0438.
} 
pérdida del protagonismo de América-MG y el surgimiento del Clube Atlético Mineiro y Palestra Itália, que reconfiguran las disputas y, en consecuencia, el diseño de las formas de animar, estableciendo un campo de membresía de club demarcado con mayor precisión en la ciudad. En este sentido, buscamos como una fuente privilegiada de investigación los periódicos locales, que describieron diariamente el deporte/fútbol belorizontino, reverberando los eventos elegidos como más significativos. A partir de la narrativa periódica, fue posible establecer una visión general de hinchas de fútbol y sus comportamientos más tipificados, vinculados a la lógica del consumo y la identidad, ilustrados por episodios como concursos de mujeres hinchas, aumento de la violencia (y, por lo tanto, el intento de controlar los modos para animar) y la apertura de espacios nuevos y adecuados, los estadios de fútbol.

Palabras clave: Fútbol; Historia del deporte; Modernidad; Animar; Belo Horizonte - MG

\section{Primeiros Apontamentos}

America F. C. - Dada a situação de decadencia a que chegou esse outr'ora modelar gremio, é de esperar-se que seus actuaes directores se movam no sentido de impedir o total desmoronamento do glorioso club. [...] Saibam os desportistas do America que seria crime imperdoável o desapparecimento, por sua incuria, dessa instituição que sempre honrou, honra e honrará o meio desportivo e social de Bello Horizonte (Correio Mineiro, 1926, p. 3).

O trecho da nota escrita por "Carpas", articulista esportivo do Correio Mineiro, atentava para a possibilidade de declínio do clube decacampeão da cidade. A perda do título do campeonato de 1926 para o Atlético e o franco desenvolvimento do Palestra faziam acender a preocupação dos muitos simpatizantes do vitorioso alvi-verde. A segunda metade da década de 1920 é indicadora de uma profunda mudança no futebol em Belo Horizonte. A quebra da hegemonia americana representava apenas um dos vários elementos que emergiram neste período. A reboque destas transformações estavam os sentidos e significados atribuídos ao torcer, mais intenso e abrangente que os anos anteriores.

Mais do que propriamente uma modificação nos modos de "torcer", os novos comportamentos e situações registravam uma hipertrofia daquilo que havia sido construído pelo que se convencionou chamar de torcida. A ideia de espetáculo e diversão, a participação da mulher, os sururus ${ }^{2}$ e a própria noção de pertencimento e paixão clubística são alçados a uma dimensão inimaginavelmente grandiosa.

\section{A Rainha dos Sports}

\footnotetext{
${ }^{2}$ Sururu era o termo adotado à época para dizer das brigas e confusões em uma partida de futebol, fossem no campo ou nas arquibancadas.
} 
O início do ano de 1927 trouxe um acontecimento que iria impactar toda a cidade de Belo Horizonte, mobilizando milhares de pessoas em torno dele. Talvez sequer o próprio Correio Mineiro não imaginasse o sucesso que alcançaria o concurso instituído por ele, denominado "Rainha dos Sports". A ideia era relativamente simples, e consistia na escolha de uma das senhorinhas representantes dos principais clubes de futebol da Capital. A mais votada, ao final da promoção, obteria o título de a "Rainha dos Sports". Os clubes ofereciam os nomes de suas "Rainhas", escolhidas por critérios diversos. Destarte, havia as "Rainhas do Atlético", as "Rainhas do Palestra", e assim por diante. Melhor explicado pelas palavras do articulista da nota, na edição em que se lançava a proposta do concurso:

Iniciamos hoje o nosso concurso para sabermos qual será a Rainha do Sport em Bello Horizonte. O votante deverá encher o coupon que publicaremos diariamente, escrevendo o nome da candidata, o club de que a mesma é "torcedora" e o seu nome. Este coupon deverá ser remettido ao redactor sportivo do CORREIO MINEIRO, para a nossa redacção, ou para a caixa postal $n^{\circ}$. 134. A apuração será feita aos sabbados e o resultado será publicado diariamente. As canditadas collocadas até o $3^{\circ}$ logar serão premiadas com lindos premios que vamos instituir brevemente e terão, tambem, estampada em nossas columnas sua photographia (Correio Mineiro, 1927, p. 2).

Para se ter uma noção da tamanha aceitação do público por parte deste evento, as notas da seção esportiva vibravam os ecos de tal movimento:

O NOSSO CONCURSO - QUAL SERÁ A RAINHA DOS SPORTS EM BELLO HORIZONTE? Cada dia que passa e o enthusiasmo dos nossos desportistas augmenta pelo resultado final do nosso concurso para a eleição da Rainha dos Sports em nossa capital. O sport, tambem, necessita de uma imagem que guie os seus athletas no campo de lucta e é por isso que tomamos esta iniciativa, que felizmente foi recebida com applausos geraes pelo mundo sportivo horizontino. Diariamente augmenta o numero de candidatas ao titulo de Rainha dos nossos Sports. Hoje já temos uma nova candidata, a senhorita Sylvia Maia, do Club Ludopedio Calafate. O Club Athletico Mineiro apresenta mais uma candidata na pessôa da distincta senhorita Lucia Morandi, que hoje começa a ser votada (Correio Mineiro, 1927, p. 2).

Certamente o periódico vislumbrou na paixão clubística uma forma de obter lucros. Cada voto representava a compra de um exemplar do jornal, haja vista a necessidade do cupom da promoção (Fig. 01) ser recortado para posterior depósito nos locais indicados. Enxergava-se também, no concurso, uma possibilidade da demarcação de um campo de forças, onde a "Rainha dos Sports" acabaria por representar a maior e mais influente torcida. 


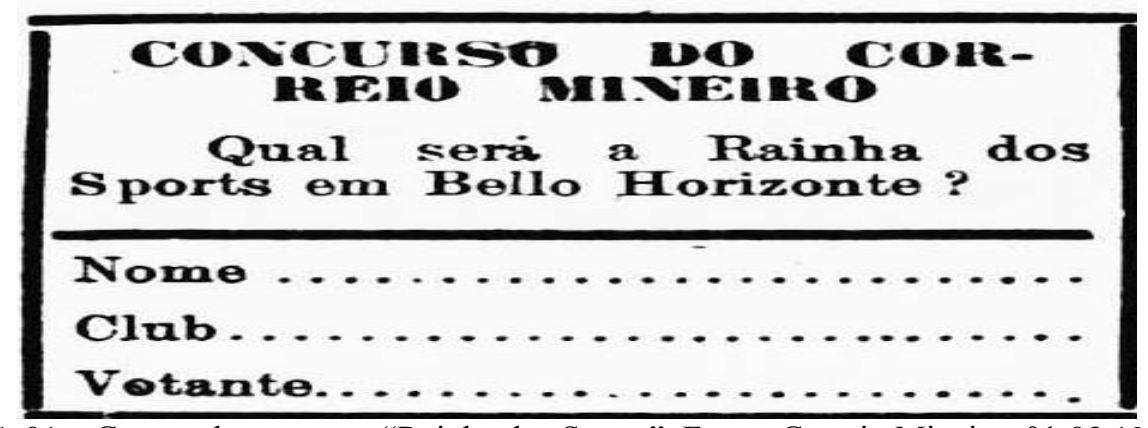

FIG. 01 - Cupom do concurso "Rainha dos Sports". Fonte: Correio Mineiro, 01.03.1927, p. 2.

O título coube à torcedora do Club Athletico Mineiro, senhorinha Nenen Aluotto. O que mais impressionava, no entanto, era a quantidade de votantes, e a diferença da primeira colocada para as demais. Nada menos que 86 mil votos foram computados na apuração final. Ora, levando-se em consideração os censos de 1920 (55.563) e de 1930 (116.981), é possível estimarmos a população de Belo Horizonte no ano de 1927 em torno de 90.000 habitantes.

86.000 mil votos representava a quase totalidade dos moradores da cidade ${ }^{3}$, e mostrava realmente a força de mobilização que o concurso atingira. As segunda e terceira colocadas receberam o título de Gran-Duquezas, cabendo às senhorinhas Horizontina Frederici (Palestra) e Amelia Vanucci (Fluminense) respectivamente, tal distinção. As fotos das vencedoras do certame foram estampadas na primeira página do jornal e ilustravam a importância dada ao evento, além de cumprir uma das promessas de premiação da disputa.

A realização deste concurso é revelador de muitos aspectos ligados ao torcer em Belo Horizonte. Primeiramente, o caráter de time popular posto sobre o Club Athletico Mineiro parecia se confirmar. A quantidade de votos destinados ao clube não deixava margem para dúvidas quanto a isto. Apenas a vencedora obteve 34.471 votos, bem mais que a soma das gran-duquezas (17.801 e 4.785 respectivamente). Porém, somando-se todos os votos destinados às torcedoras do Athletico, tem-se o expressivo número de 35.056, o que equivale dizer que $40 \%$ do montante de votos tomaram a direção da equipe alvi-negra.

Por outro lado, o América justificava a preocupação de parte da imprensa e da torcida quanto à sua decadência. A americana melhor colocada no concurso ficou com a pouco honrosa colocação de sétimo lugar, com 3.285 votos recebidos. Ao todo, o clube alvi-verde arrebanhou 5.194 indicações, distribuídas entre as candidatas que o representavam.

\footnotetext{
${ }^{3}$ Importante destacar o fato de uma mesma pessoa poder depositar vários votos, o que indica que não foram necessariamente 86 mil pessoas votantes. Ainda assim, este número é bastante significativo, levando-se em consideração a adesão à proposta do concurso.
} 
Percentualmente, o time da elite conseguiu obter pouco mais de $6 \%$ dos votos, ficando atrás do clube da colônia italiana, o Palestra, que obteve 18.220 indicações (21\%).

A entrevista dada ao periódico pela recém-eleita Rainha dos Sports e torcedora atleticana Nenen Aluotto demonstrava o pertencimento arraigado pelo clube, onde em um trecho se destacava:

- $\quad$ Qual o sport de sua predilecção?

- Para assistir, prefiro o "foot-ball”, para jogar "cap-ball”.

- $\quad$ Torce ha muito pelo Athletico?

- Ha muito tempo!

- Depois do Athletico, qual o club da sua sympathia?

- $\quad$ Gosto de todos os clubs.

- Na sua opinião, qual o club que levantará o campeonato deste anno?

- O Athletico, está visto (Correio Mineiro, 1927, p. 2).

E a jovem torcedora, de 14 anos incompletos, não ficava apenas no discurso. Frequentadora assídua dos campos horizontinos, especialmente aos jogos do Athletico, Nenen Aluotto encarnava o espírito de torcedora, incentivando e sofrendo pelo seu clube de coração. $\mathrm{Na}$ foto abaixo (Fig. 02), a menina de alma alvi-negra posa junto aos campeões de 1926, um ano antes da realização do concurso:

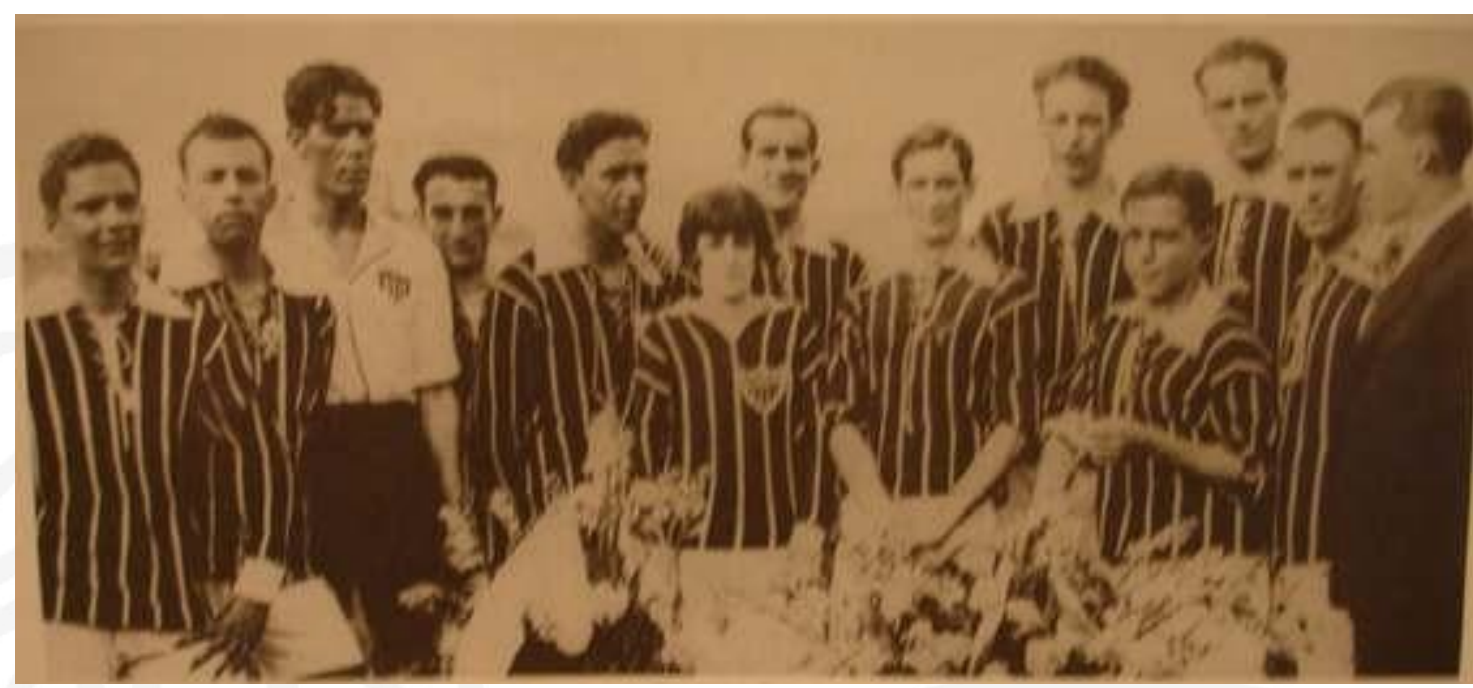

FIG. 02 - Foto do Club Athletico Mineiro, campeão de 1926. Fonte: Acervo Clube Atlético Mineiro.

\section{Velhas e novas rivalidades: sururus e uma educação para o torcer}

A conquista do bicampeonato em 1926-1927 pelo Club Athletico Mineiro acentuava a rivalidade entre este clube e o America. A presença do Palestra criava uma nova percepção de luta e oposição, mas não dirimira a antiga emulação existente entre os tradicionais times da Capital. O semanário “independente, humoristico e desportivo" Gazeta Esportiva, explicitava 
a posição de rivais históricos que Athletico e America possuíam. A manchete da primeira página enfatizava tal condição, ao estampar:

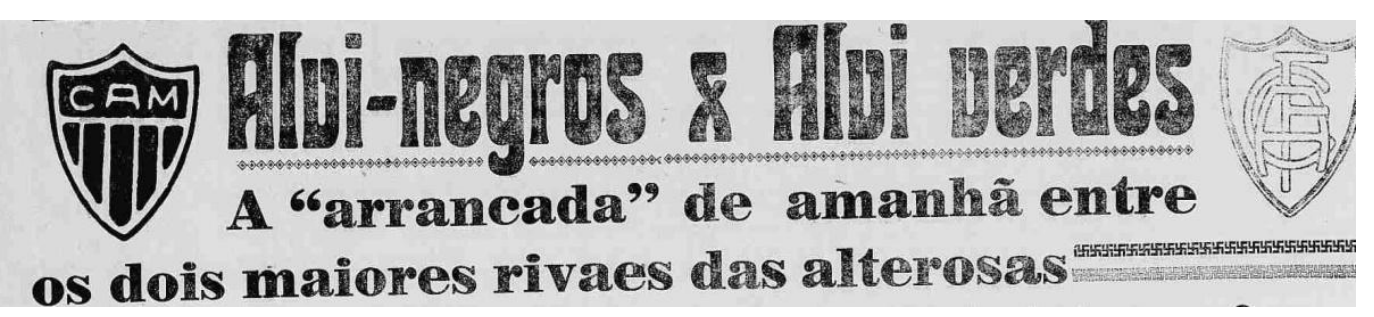

FIG. 03 - Chamada da $1^{\text {a }}$ página do jornal Gazeta Esportiva, em 10.12.1927.

A importância deste confronto também poderia ser medida pelas palavras do jornalista, ao descrever na nota referente do embate entre Athletico e America que "o jogo de amanhã é esperado com grande ansiedade nas rodas esportivas de Bello Horizonte: os teams do America e do Athletico sempre que se encontram, revolucionam o desporto mineiro" (Gazeta Esportiva, 1927, p. 1).

Em 1928, o encontro entre os quadros do Athletico e do America não despertavam menor entusiasmo daquele ocorrido no ano anterior. Na visão do periódico Minas Geraes, "[...] o renhido embate, realizado no belo "stadium" do America, cujas obras se acham quase concluidas, foi assistido por uma multidão que podia ser calculada em perto de 15.000 pessoas" (Minas Geraes, 1928, p. 8). A percepção da quantidade de público se tornara um importante referencial do status que algumas partidas alcançavam. Neste sentido, Atlético e América reuniam sempre uma considerável massa de torcedores. Algumas divergências entre o tamanho do público eventualmente ocorriam entre os periódicos, que não dispunham de um instrumento de medição preciso. Neste mesmo jogo, o "semanário de sports e humorismo", $O$ Pirolito $^{4}$, estampava, na primeira página, uma fotografia do aspecto das arquibancadas do inacabado estádio americano, repleto de torcedores. Observava-se, na chamada da reportagem, o destaque dado aos 12.000 assistentes, uma diferença de 3.000 pessoas, comparando-se com a nota do Minas Geraes.

Se a disputa fazia nascer sentimentos elevados nos sujeitos da torcida, o resultado do embate gerava desdobramentos que evidenciavam a paixão e o pertencimento clubísticos, percebidos no entusiasmo da vitória ou na dor da derrota. A partida final do campeonato de 1927 entre os Alvi-Negros e os Alvi- Verdes, embora já sendo campeão o Athletico, dividia a cidade em duas côres e duas paixões distintas. E o placar iria induzir a uma série de posturas

\footnotetext{
${ }^{4}$ O Pirolito, edição de 10 de set. de 1928.
} 
dos dois lados. A vitória do América por 3 x 2 causaria reações diversas em muitos torcedores. Na seção Schoots, a Gazeta Esportiva dava vazão às sensações pós-jogo, e reportava:

\begin{abstract}
Na Avenida Paraopeba, bando de alegres mocinhas, caminhavam em demanda da cidade. Umas deixavam transparecer visiveis traços de uma profunda tristeza, motivada pelo resultado do jogo entre os grêmios americano e alvi-negro. Outras numa incontida alegria embevecidas pela victoria do quadro alvi-verde, enflorava aquella avenida com seus gestos graciosos, acompanhados daquelles sorrisos que demonstram uma alegria sem par. Estacionados como maliciosas estatuas de sal, a sorrirem dos torcedores do club vencido, estavam o Farah, o Scarpelli, Longo e Rubem. Junto a elles passa um grupo de torcedoras do Athletico. O Scarpelli, que é um segundo D. Juan, dirige a uma daquellas "pequenas", uma "piada". Aquella, vivamente irritada, abalada ainda pela derrota do seu club, responde-lhe: - o senhor pensa que o Athletico apanha de 9x2 como o Palestra, "seu" italiano? (Gazeta Esportiva, 1927, p. 2).
\end{abstract}

A incontida paixão tornava colérico o mais fleumático simpatizante. No caso específico de Flexa, alcunha de um dos jogadores do América, a linha que dividia o footballer do torcedor era extremamente tênue. A sua atitude após a partida contra o Atlético foi assim narrada:

Foi no domingo, dia do jogo America x Athletico. Tinha terminado o jogo com a victoria do alvi-verde. Tomado de extranha sensação o Flexa que é americano do papo... vermelho, confunde-se com a torcida e invade o campo, pulando como um macaco e dançando divinamente o charleston. $\mathrm{O}$ nosso "homenzinho", toma afinal a frente dos seus collegas e virando-se para as archibancadas da torcida athleticana, dando pulos, torcendo o bigodinho e vermelho como um peru, grita: - Ide! E dizei a toda a gente, que o America "esculhambou" o Athletico (Gazeta Esportiva, 1927, p. 2).

O bicampeonato de 1926-1927 do Athletico, e a conquista dos títulos de 1928-19291930 pelo clube italiano revelavam uma nova composição de forças rivais e acentuava a disputa entre ambos. Se a primeira metade da década de 1920 assistiu à consolidação do acirramento entre America e Athletico, a outra metade celebrou a construção de uma rivalidade que se tornaria histórica. Os jornais da época regurgitavam de notícias sobre este confronto, e anunciavam a intensa movimentação na cidade, em instantes que precediam o esperado embate. Uma das formas mais explícitas de paixão entre os clubes estava no ato de apostar. E apostar começava a fazer parte da rotina dos jogos de futebol em Belo Horizonte, principalmente quando os grandes se enfrentavam. A partida entre o Palestra Itália e o Athletico Mineiro, em junho de 1930, exemplificava este estado de coisas, como na descrição do anúncio do jogo pela seção esportiva do Minas Geraes, que trazia: 
Sim, é hoje. Data historica. O maior dia deste anno. Gente vibrando de enthusiasmo puro. E outros misturando enthusiasmo com ambição. Grandes apostas no Athletico e no Palestra. Segunda-feira, novos ricos. E sujeitos tristes, exactamente como aquelles que gastam tudo no Carnaval. Shoot valendo dinheiro. Apostas de contos de réis. Mas si o jogador fôr profissional, campanha contra elle. Que importa! São os apostadores que animam o jogo com as brigas (Minas Geraes, 1930, p. 12).

Fazia-se de tudo na torcida pelo time predileto, ainda mais quando esta "torcida" valia alguns milhares de réis. Estar presente em campo, gritando e vibrando (ou brigando, como indicava a nota acima) com o desenrolar do jogo, nem sempre era suficiente para garantir a conquista da vitória. Os casos de "ajuda espiritual" surgiam como recurso de incentivo, principalmente quando as apostas em dinheiro se associavam ao torcer. O periódico Goal apresentava uma matéria intitulada "Macumba", que bem ilustrava a situação apontada. Nela, o texto traz à tona reveladores e importantes hábitos constituídos pelos torcedores, nos anos finais da década de 1920:

Os torcedores do Palestra e do Athletico fizeram apostas a semana inteira. Dentro dos cafés, muita gente sonhou com a victoria do club e com melhores planos de restauração financeira. Essa grande agitação foi principalmente notada pelas agencias de loterias, prejudicadas com o grande interesse despertado pelo jogo de domingo. Ganhar dinheiro torcendo, é muito mais agradavel do que esperar que as bolinhas cahiam com o numero. A semana foi péssima para os cambistas. [...] Emquanto o pessoal casava os cobres aqui na Avenida, Braulino, o mais inspirado e subtil dos apostadores, embarcou para Matheus Leme. Queria que um velho feiticeiro garantisse a victoria que elle, cheio de enthusiasmo, já desejára ao Athletico, apostando nelle mais de quinhentos mil réis. E Braulino ouviu surprehendido, esta resposta: - Ê moço, ocê veio tarde. Já teve aqui o sr. Hugo Savassi, que me pediu p'ra pôr os pausinhos p'ro Palestra ganhá (Goal, 1930, p. 3).

A crônica desta partida no Minas Geraes é a narração precisa do movimento estabelecido pelo torcer na Capital mineira, e indica elementos fundamentais para a compreensão do lugar ocupado pelo futebol e pelas torcidas na cidade. Nela, o cronista vai da expectativa que antecede o jogo à frustração e alegria dos torcedores. Sobre os momentos que antecediam ao confronto, o texto descrevia:

Quasi que não havia missa das dez. O povo tinha pressa de ver si o Athletico, naquelle dia bellissimo de ante-hontem, conseguiria desfazer a influencia da sua falta de sorte tradicional. Os retardatarios sahiram da egreja ás onze horas e correram para o campo. As archibancadas já estavam cheias. Cedo ainda, havíamos assistido os preparativos da commissão de Finanças do Athletico, dirigida por Fabio Brant. $O$ thesoureiro escalava os auxiliares, distribuindo malas, que em poucos instantes se encheram assombrosamente com os cobres daquella torcida apressada. Vinte mil pessoas. Ninguem contou. Mas toda a gente calculava assim. E o proprio Mario de Castro, que é espírito observador, tambem affirmava: - Eu previa esta assistencia. Eu sabia que hoje isto ia ficar assim. Alda e Natividade, sem tempo de almoçar, 
comiam biscoitos, com uma naturalidade que já estava chamando a attenção de todos. Benedicto, da Imprensa Official, estava firme no meio de umas athleticanas bonitas, que elle descobriu e conquistou no Barro Preto. Já não havia logares. Tudo apertado. Por isto, houve indignação quando uma mulher enorme, typo Studebacker, foi pedindo licença e derrubando gente no caminho. A hora do jogo veiu, poderosa, destruindo todas as attenções dispersas. Fazendo esquecer as contrariedades da vida. Approximação da hora tragica. Comparações passadistas dos minutos que são eternidade. Arrepios no corpo. Physionomias mostrando a inquietação interior. Nervos, fios encobertos de electricidade (nós andavamos doidos para escrever isto). Ansiedade de sujeitos malucos que fizeram apostas (Minas Geraes, 1930, p. $11)$.

Como não há uma estatística oficial de público para esta partida, os vinte mil presentes poderiam representar um exagero entusiástico do cronista, mas apontava para uma quantidade considerável de pessoas na assistência do jogo. Para se ter uma ideia, praticamente $20 \%$ da população da cidade estaria presente ao campo. Para efeito de comparação (guardando todas as variáveis anacrônicas), é como se em um confronto entre as duas equipes hoje, comparecessem cerca de 500.000 espectadores, ou ainda em torno de seis mineirões completamente tomados. Embora a quantidade seja um parâmetro importante, os comportamentos do público também instigavam apontamentos significativos. À parte a espera e a expectativa relatada na crônica, o desdobramento do confronto mostrava as plurais reações dos torcedores. Em outra parte, a narrativa seguia afirmando:

O jogo Palestra e Athletico é o que consegue reunir em campo o maior numero de pessoas. E o de ante-hontem até fez com que Bello Horizonte visse caras inteiramente desconhecidas, de velhos e modestos italianos, que vivem retrahidos no trabalho. Alguns nem sabiam torcer. Mas, por instincto, dahi a pouco elles tambem acertavam e se entendiam em lamentações, si o Palestra shootava por cima: - Per la madona. Impossibile. [...] Chico Velloso foi notavel nas cabeçadas. José Alexandre defendeu penalty. Foi mesmo o segundo team que começou a enrouquecer a torcida do Athletico, a maior da cidade. O Palestra tinha um terço da assistencia. [...] O Palestra foi inventado em Bello Horizonte para vencer sempre o Athletico. E o Athletico foi fundado para vencer cariocas e paulistas. Compensações. O privilegio de dois clubs. Quando Mario de Castro ia bater o penalty, uma athleticana bonita, do grupo das meninas do Benedicto, ficou afflicta: - Elle acerta. Deus é grande! - Sim, respondeu outra moça, branca como um bilhete de loteria. Deus é grande, mas o "goal" é muito menor. E Mario de Castro shootou por cima. Arthur Martini, um rapaz que ganhou dez contos de réis nas apostas de ante-hontem, falava em defesa do Palestra: - Mêdo nós não temos. [...] E agora nada mais de football. Esse jogo de domingo está continuando feroz na Avenida, no Iris e no Excelsior. Vocês viram aquella bola que passou por cima? E aquella outra, muito differente, que passou por baixo? O Palestra póde recordar o jogo, porque venceu. Mas o Athletico deve esquecel-o, exactamente porque reconhece a sua derrota (Minas Geraes, 1930, p. 11). 
O tom de algumas crônicas narrativas nas partidas entre o Atlético e o Palestra parecia prever o desdobramento futuro dessa rivalidade. Em um confronto entre estas duas equipes, ocorrido no dia 09 de junho de 1929, a descrição das sensações despertadas ante o embate dos clubes denunciava o advento de uma nova e intensa emulação:

O domingo sportivo despovoou muito centro o centro da cidade. Bello Horizonte ficou sendo o campo do Athletico. Ao meio-dia, a multidão da torcida começou a movimentar-se. Automoveis cheios. Omnibus andando pesadamente. Subindo o morro, grandes grupos de gente apressada davam a idéia de uma emigração penosa. Quando, afinal, chegavam as proximidades do "stadium", todos precipitavam-se na conquista de um logar. Nas archibancadas, quasi cheias, os espaços iam desapparecendo. Moças. Senhoras. Familias inteiras, puxadas por homens que abriam caminho, ás vezes sem pedir licença. Espectadores calmos, com a mania da estatística, fazendo cálculos. 15.000... 18.000... - De um lado da archibancada a torcida do Athletico, a maior da cidade. Do outro, a do Palestra. Na geral e em toda a parte, ainda a torcida do Athletico, prolongando-se até fóra do campo. Vibração em todos os grupos. Previsões exaggeradas. Palpites. Curiosidade de saber o nome do juiz. E os retardatarios entrando, incommodando. Pedidos de desculpa. Revoltas intimas. Murmurações sobre a delicadeza e a sua necessidade. - [...] As torcidas entreolham-se. Palestra! Athletico! [...] Começa então a verdadeira ansiedade. As emoções consideráveis e definitivas. Os athleticanos, já triumphantes, esperando a victoria nova. Os palestrinos mexendo no arquivo dos campeonatos. Gritando resultados antigos de outros jogos. E o "stadium", enorme, cheio, lembrando o jogo do Corinthians. Os athleticanos confiantes. [...] Poucos minutos para terminar. Palestra, três goals. Athletico, um. A archibancada começa a esvaziar-se. Algumas brigas de torcedores. Murros e confusão. É quase noite. Os palestrinos ficam até o fim. E a torcida do Athletico retira-se, convencida da magnifica victoria dos jogadores de camisa verde (Minas Geraes, 1929, p. 12).

Se antes o futebol despertava o interesse de uma reduzida classe de pessoas, a dos desportistas convictos, a segunda metade da década de 1920 revelava a grandiosa apropriação do universo futebolístico em Belo Horizonte, com dezenas de milhares de indivíduos ligados à rotina dos jogos e campeonatos ocorridos na cidade. Por toda a parte podia-se ouvir alguém se declarando adepto de uma ou outra agremiação esportiva, notadamente dos clubes de futebol. Tanta gente envolvida fazia crescer também os incidentes, um eufemismo muito utilizado pela imprensa local para designar as brigas ou sururus, naquele instante algo praticamente inerente às partidas. $\mathrm{O}$ aumento da paixão elevava a rivalidade, e por consequência, os conflitos.

Norbert Elias, ao se debruçar sobre o processo civilizatório, elabora, em um dado momento da sua obra, uma relação entre o esporte, a violência e as emoções vivenciadas no mundo esportivo. Sobre isto, chega a afirmar a existência de uma relação entre as formas de conflito com formas de interdependência, na tentativa de estabelecimento do nosso grupo e do 
outro (outsiders), através de emoções como o prazer e o sofrimento (ELIAS, 1994). A constituição das torcidas, da rivalidade e dos confrontos é um processo que reflete, em parte, o pensamento de Elias.

$\mathrm{Na}$ existência do conflito é que o controle social passa a vigorar. Controle que o sociólogo alemão, em A Busca da Excitação, percebe nos dispositivos de coerção sobre os comportamentos violentos, seja através dos discursos, das práticas normativas, dos poderes institucionalizados em maior ou menor medida e nos mecanismos de autocensura ou autocontrole (ELIAS e DUNNING, 1992). A evidência dessa "normatização de condutas" ocorre nas tentativas de instauração de um ordenamento do torcer em Belo Horizonte.

São inúmeros os indícios dos sururus localizados nos periódicos, neste período. Junto à maior incidência dos confrontos entre as torcidas, uma tentativa de minimizar a sua ocorrência pode ser percebida, com a instituição de uma "maneira adequada" de torcer, ou ainda, de uma "educação para o torcer", onde diversas ações passaram a ser adotadas. Em uma partida entre o Athletico e o America, a diretoria deste anunciava uma série de medidas, publicada na imprensa através de uma resolução que determinava, dentre outras coisas:

Para conhecimento de todos, a directoria do America, em sessão de quintafeira ultima, resolveu tomar as seguintes providencias que serão rigorosamente mantidas:

$1^{\text {a) }}$ Estão expressamente prohibidos os ditos chulos, as vaias, arrebentar bombas e os assobios;

$8^{\mathrm{a}}$ ) Serão postos fóra do recinto do estadio os que não se comportarem com a devida decencia, entrando a directoria do club, para isso, em combinação com o sr. delegado que fôr presidir o encontro desportivo de 9 do corrente; $\left.9^{a}\right)$ O policiamento interno, superintendidos pelos directores do club, terá como chefe o capitão dr. Magalhães Góes e como seus auxiliares os seguintes socios: Odorico Celso, Ormesindo de Barros, Calogeras Mangeracini, Heitor Gomes, Dermeval Ferreira de Carvalho Symphronio Fidelis, Edgard Vieira, João Carvalho, João Lopes de Moura Filho, Luiz Inneco e Decio Quadros, que terão uma braçadeira branca e verde (Minas Geraes, 1928, p. 11).

Se os assobios e as vaias das torcidas deveriam ser banidas do campo de jogo, sob pena de expulsão da arena esportiva, outro rol de práticas, muito mais inconvenientes (e perigosas) acontecia recorrentemente: as brigas entre os torcedores, que deixavam rastros de preocupação em diversos setores da sociedade. A exigência do policiamento se justificava a medida que os "incidentes" já não mais se atinham apenas às discussões de outrora. A reclamação do Correio Mineiro parecia pertinente, ao apontar a falta de policiamento em algumas partidas. A nota se referia às consequências danosas que a ausência da autoridade policial poderia causar, e afirmava: 
Hontem demos uma noticia ligeira a respeito da não realização dos encontros da serie B no campo do Prado Mineiro, e hoje que estamos melhor informados temos que lamentar as causas que determinaram a suspensão dos encontros acima referidos. A Liga Mineira, de accordo com o regulamento da policia, requereu a respectiva licença para os jogos da serie B e pagou os sellos devidos, tendo pedido, portanto, o policiamento para aquelles jogos e entretanto lá não appareceu nem siquer um policial, dando isso causa a serios conflictos que se desenrolaram pela manhã, havendo até aggressão à mão armada. [...] Na serie B, existem clubs que tem a sua "torcida" composta de distinctas senhoritas e estas já tem sido por algumas vezes desrespeitadas por indivíduos sem educação que se aproveitam da occasião para insultar a assistencia (Correio Mineiro, 1927, p. 3).

O periódico Gazeta Esportiva, em uma seção intitulada "Ha 32 annos", atentava para o fato de que, há muito tempo atrás, "alguns jogos de futebol, realizados nesta capital, ainda não terminavam em sururu's" (Gazeta Esportiva, 1928, p. 2); um exagero temporal, certamente; porém um importante indício de que as brigas entre os torcedores se tornaram, de fato, comuns nos campos de futebol.

Um artigo publicado na Folha Esportiva, intitulado "Bom Meio de Manter a Ordem”, trazia uma solução proposta pela Inglaterra para o arrefecimento dos ânimos exaltados dos torcedores. Ao apresentá-la, o cronista esportivo descrevia as suas impressões sobre os "incidentes" nos campos horizontinos, e oferecia a alternativa inglesa como possível forma de resolução dos conflitos:

É costume, nos campos de competições athleticas, em Inglaterra, usarem, para a manutenção da ordem, bombeiros, em vez de policemen. São modos que à primeira vista, parecem absurdos, mas que, analysados melhor, nos patenteiam o espírito pratico dos inglezes. Aqui em nossos estadios, quando ha sururú, os visinhos adherem, a policia entra em scena, os soldados arrancam as durindanas e brigam mais que os próprios provocantes, etc. [...] $\mathrm{Na}$ Inglaterra não ha senão o seguinte: basta esboçar-se um "camarote" para os bombeiros ligarem as grossas bombas e dirigindo-as para os exaltados, apagarem o seu "fogo". E isto sem si importarem se molham uns aos outros. Na verdade é um optimo meio, porque, vendo uma briga, não ha quem não queira "tirar uma casquinha", mas ninguem quer ir para casa molhadinho como um pinto (Folha Esportiva, 1930, p. 7).

Apesar do apelo do jornalista, o espírito prático dos ingleses jamais chegou a ser utilizado como recurso de contenção dos confrontos nos campos de futebol em Belo Horizonte. Os principais métodos de apaziguamento consistiam mesmo na intervenção da força pública policial, com o auxílio, em alguns casos, do policiamento interno propiciado pelos principais clubes.

Em outros casos, era o próprio discurso oficial - "dos poderes institucionalizados, em maior ou menor medida" - que se incumbia de ordenar e orientar as condutas dos torcedores. 
Na partida entre o selecionado mineiro e o Fluminense, em 1929, a Associação Mineira de Chronistas Desportivos “distribui, profusamente, no campo, o seguinte boletim”:

\begin{abstract}
Mineiros!!! Sabei que estão em jogo o bom nome e o cavalheirismo do povo mineiro. Lembrae- vos de que os bravos rapazes fluminenses não vieram á nossa terra em busca de inexpressivas victorias por supremacia de score. Vieram, sim, estreitar mais um laço de amizade que une os filhos de Minas aos filhos do Estado do Rio. Recebei- os, pois, como recebeis os vossos próprios irmãos. Applaudi-lhes os feitos brilhantes no campo de lucta desportiva. Sem uma palavra, nem um gesto menos digno que os possa offender. Honrai as tradições de cultura e civilidade da hospitaleira gente montanheza. É o que vos pedem os moços da Associação Mineira de Chronistas Desportivos" (Minas Geraes, 1929, p. 20).
\end{abstract}

No entanto, os sururus não se restringiam aos "pescoções" e confrontos físicos. Ofensas e insultos passaram a fazer parte do repertório de armas para atingir o adversário. Em uma carta redigida por Americo Gasparini, em 10 de setembro de 1928, e publicada no dia seguinte no jornal $O$ Estado de Minas, o autor (presidente do Palestra) se mostrava revoltado pela publicação de uma correspondência do suposto palestrino Antonio Marianneli, que tecia duras críticas ao comportamento da torcida atleticana em um confronto com o rival Palestra. Gasparini tentava esclarecer, indignado, que o teor da carta do provável torcedor italiano continha uma série de equívocos e aparava as arestas, apontando:

Ilmo. sr. redactor do "O Estado de Minas" - Surprehendeu-nos hontem, à directoria do Palestra Itália e aos palestrinos, uma carta cheia de injurias e de insensatez publicada na secção sportiva do "O Estado de Minas". O signatario de tal carta não é socio do Palestra e nem é conhecido nesta cidade. Nenhum palestrino, digo mais, nenhum sportman seria capaz de escrever aquillo. Certamente, foi obra de espírito mal intencionado com o objectivo evidente de fazer crear, em torno do glorioso Palestra, uma atmosphera de rivalidades e odios. Depois do jogo do dia dois do corrente, entre o Athletico e o Palestra houve, é exacto, pessoas que, em nome do Athletico, se excederam, transpuzeram os limites do razoavel e da decencia. [...] Agora estes, ou alguns delles, que não são, não podiam ser e nunca foram athleticanos, no intuito mal disfarçado de obter os applausos que a opinião sensata lhes negou, vêm, usando de um nome imaginario, e em nome do Palestra, escrever a carta publicada inadvertidamente pelo seu jornal (O Estado de Minas, 1928, p. 6).

Um outro fato que mereceu atenção da imprensa foi a publicação de um comunicado anônimo, no Bar do Ponto, com ofensas indizíveis. Com o título de "O Espírito Engarrafado de Certos Torcedores Ranzinzas e Imbecis", o jornal trazia uma nota sobre o ocorrido, na qual descrevia:

Infelizmente o meio sportivo da Capital ainda conta em seu meio com elementos profundamente curtos de intelligencia e falhos da mais leve tintura de educação, inteiramente enfermiços do cerebro. Ainda hontem, talvez procurando fazer espírito engarrafado, affixaram no Bar do Ponto, um 
communicado anonymo que aqui não transcreveremos para não nos nivelar à indecencia e a baixeza de quem, numa hora infeliz, o escreveu e deu, assim, prova de tão perfeita imbecilidade e completa ignorância ( $\mathrm{O}$ Estado de Minas, 1928, p. 5).

Todo este clima hostil do futebol nas arquibancadas, oriundo da rivalidade entre as preferências clubísticas, levantava questionamentos inclusive sobre a sua legitimidade enquanto prática social permitida e vivenciada. O escritor carioca Coryntho da Fonseca, redige um artigo em dezembro de 1929 e publicado pelo Minas Geraes em janeiro de 1930, suscitando dúvidas quanto à importância social do futebol e criticando veementemente os conflitos gerados a partir da paixão exaltada de torcedores e jogadores. O texto, sob a denominação “O Foot-Ball não Merece o Título de Desporto”, surgia na seção Desportos do periódico oficial, e descrevia o seguinte entendimento do autor sobre o esporte bretão e seus admiradores:

[...] Não conheço, aqui, nem um caso de uma "court" de tennis ser invadida pela assistencia, impondo a introducção da cavallaria policial para desatar sururus ou para garantir os "referees" nem, ainda menos, para conter os próprios jogadores atracados aos bofetões e ponta-pés. Por maioria de razão não consta na história dos desportos aquaticos que, uma só vez que fosse, a pista tivesse sido invadida pelos "torcidas" [...]. Não ha partida de football que não exija a comparencia de um policiamento reforçado. E não policiamento que se faça por motivos geraes de garantia da ordem em grandes agglomerações occasionaes. Nos campos de football, em todos os dias de partida, o policiamento nunca é, platonicamente, preventivo. Tem de ser repressivo. O "sururu" é do programma, não só entre o publico assistente, em que, de resto, não se podem apurar selecções esmiuçadoras, mas entre os proprios desportistas que tinham a obrigação funccional do bom exemplo de correcção de maneiras. [...] Mesmo que grandes e excepcionaes fosse (sic) as virtudes do football, para a educação physica, taes virtudes não acham compensação, nos seus lamentaveis effeitos de deformação moral, tanto da assistencia como dos jogadores. [...] Um desporto que suggere pensamentos de morte, que provoca, na multidão, gritos de lynchamento, não pode ter, não merece ter $\mathrm{o}$ nome de desporto, de meio louvavel para $\mathrm{o}$ desenvolvimento physico da raça (Minas Geraes, 1930, p. 14).

\section{Um estádio para chamar de seu}

Provocar o outro (outro time, outra torcida, outro torcedor) constituía-se em um desdobramento da paixão e do pertencimento. O outro só existe à medida que existe o meu time. Neste período, muitas situações contribuíram para o desenvolvimento do sentimento arraigado de torcer. Uma das mais importantes, no entanto, esteve na construção do estádio atleticano. Com o nome do Presidente do Estado $^{5}$ à época, o estádio Antônio Carlos

\footnotetext{
${ }^{5}$ Presidência do Estado era um cargo político equivalente a Governador do Estado.
} 
representaria uma nova possibilidade de assistir às partidas de futebol na Capital, quer pela sua dimensão grandiosa, quer pela sua estrutura e localização. A sua inauguração reverberou intensamente na imprensa, podendo ser localizado uma gama extensa de referências a tal acontecimento, principalmente por ter o Atlético convidado o Corinthians Paulista para o jogo inaugural. O Minas Geraes, por exemplo, tratava a nova praça de esportes atleticana como "a melhor do Estado e uma das maiores do paiz"(Minas Geraes, 1929, p.10) e especificava as obras do estádio, relatando:

\begin{abstract}
As archibancadas, circumdando o campo em fórma de U, e comportando em lotação 15.000 pessoas, são de duas categorias: as geraes, descobertas; e a parte nobre, toda abrigada por uma cobertura. Esta ultima, com 80 metros de comprimento, formando fachada sobre a rua Rio Grande do Sul, divide-se em três partes distinctas, com entradas independentes e cada uma servida pelo seu bar com hygienicas e confortaveis installações sanitarias. As partes lateraes, se destinam aos assistentes contribuintes e a central é reservada aos socios, com accommodação especial para chronistas desportivos, membros da directoria e convidados de honra (Minas Geraes, 1929, p.11).
\end{abstract}

O aumento da capacidade de público e o atendimento a questões ligadas à higiene e ao conforto davam prova de uma nova mentalidade, mais atenta a aspectos relacionados à demanda de consumo, cada vez mais ampliadas. A inauguração do estádio Antônio Carlos, com a realização da partida entre o Atlético e o Corinthians, era de fato tão significativo para a cidade, que o próprio comércio local indicava, na sua postura, tal condição:

CASAS COMERCIAES QUE FECHAM HOJE - Para que os seus empregados possam assistir ao grande embate entre o Athletico e o Corinthians Paulista, ficarão fechadas hoje as seguintes casas commerciaes da nossa praça: Casa Conto, Casa Hermany, Joalheria Padua, Sapataria Central, Oliveira, Costa \& Comp., Joalheria Diamantina, Marcello de Oliveira \& Souza, Casa Caldeira, Casa Machado Coelho, Casa Ferreira, Parc Royal, Casa Guanabara, Casa Para Todos, Casa Teixeira Neves Filho, Casa Antonio d'Almeida, Casa Crystal, Casa Selecta, Casa Oscar Marques, Casa Omega, A' Sedan, Casa Saliba, Casa Royal Stores, A' Auxiliadora e Papelaria Brasil (Minas Geraes, 1929, p. 11).

Poucas situações teriam força suficiente para paralisar boa parte do comércio. O futebol e as suas representações simbólicas impactavam a cidade com uma intensidade não percebida (ou não possível) em outras práticas sociais. A foto da inauguração do campo atleticano (Fig. 04), diz muito do espaço ocupado pelo esporte bretão em Belo Horizonte, naquele instante. 


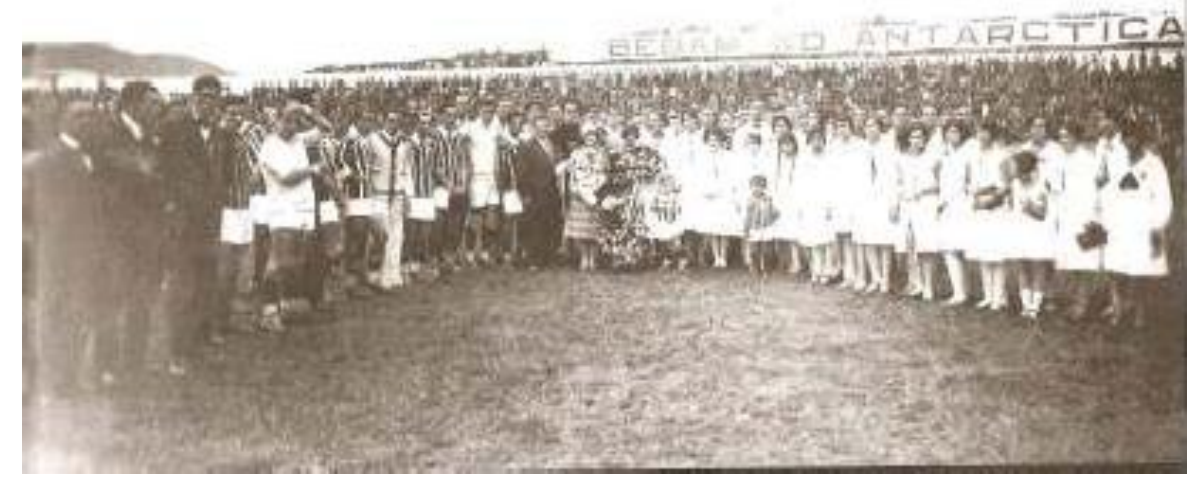

FIG. 04 - Inauguração do Estádio Antônio Carlos, em 30.05.1929. Fonte: Acervo Clube Atlético Mineiro.

O campo completamente tomado, com ares de solenidade, é a ilustração incontestável da influência com que o futebol cobrira a cidade. Pode-se ver, na imagem, uma espécie de "torcida feminina uniformizada", indicando não apenas a manutenção da presença da mulher no universo esportivo, como também uma participação maior e mais ativa. Outro destaque visual, que não poderia passar despercebido, é a publicidade de uma marca de cerveja, ocupando um enorme espaço acima das arquibancadas, demonstrando que a paixão futebolística começava a ser vista como uma fértil possibilidade de apropriação e consumo de produtos.

Receber cerca de $30 \%$ da população da cidade em um único evento esportivo mostrava a dimensão que o futebol tomara em Belo Horizonte, trazendo a reboque a (re)construção de vivências que se situavam em sua órbita. Dentre elas, uma das mais importantes residia no hábito de torcer, a esta altura algo já sedimentado na Capital mineira. O "soberbo espetáculo jamais visto em todos os tempos" dependia, necessariamente, de uma platéia que o absorvesse, e neste sentido, a constituição das torcidas era não somente importante, como também parte integrante e indissociável do espetáculo esportivo do futebol. Ir aos estádios e campos acabou se tornando um dos programas favoritos dos habitantes. A ponto mesmo de, aos domingos sem futebol, receberem a denominação de "domingos vasios" (Estado de Minas, 1930, p.7).

Assim, as partidas de futebol recebiam um público invariavelmente grande. Mas o aspecto distintivo ainda imperava, com a divisão de espaços próprios e específicos para cada tipo de platéia, dentro da torcida por um mesmo time. O confronto America x Queluziano 
expunha, imageticamente, tal condição. Na foto que estampava em plano geral o aspecto das arquibancadas, é possível distinguir dois tipos bem diferentes de público: a geral e as arquibancadas compunham dois universos em separado:

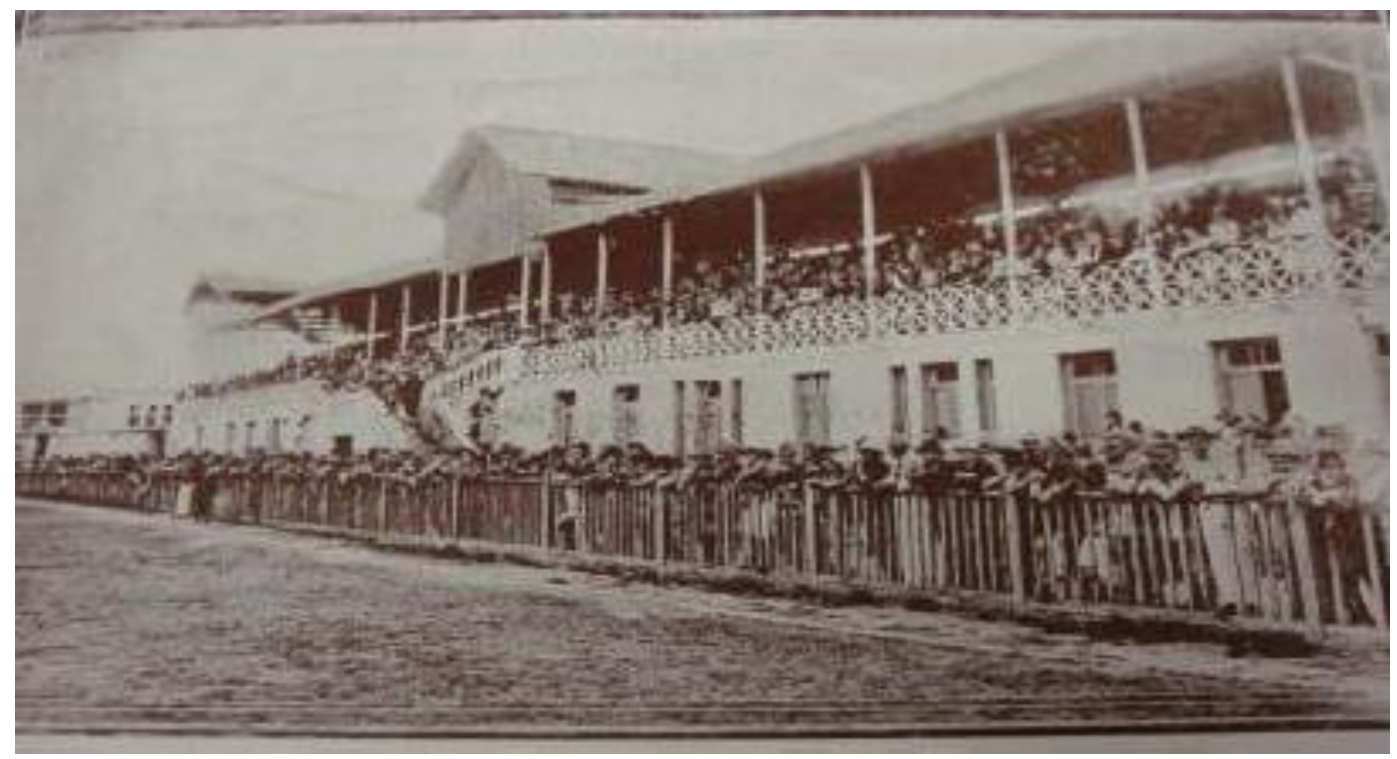

FIG. 05 - Foto da partida entre o America e o Queluziano, notando-se a geral e as arquibancadas. Fonte: SEMANA Illustrada, n. 14. Belo Horizonte, 04 set. 1927.

$\mathrm{Na}$ fácil vitória da equipe alvi-verde pelo placar de 5 x 0, o Correio Mineiro trazia uma nota descrevendo aspectos gerais da partida. No trecho da nota intitulado "A assistencia", o periódico destacava:

A assistencia no campo americano foi bôa. Lá vimos o sr. cel. Lindouro Gomes, presidente do America; ás senhoritas Lindorinha Gomes, Hilda Pedercini, Angelica Henriot, Altair Gomes, Lourdes Regato, Adalgiza Gomes, Yolanda Pedercini, Marietta Barros, Hilda Paula Ricardo, Thereza Barros, Celia Lana, Amelia Lana e muitas outras pessoas cujos nomes não nos foi possivel tomar (Correio Mineiro, 1927, p. 3).

O destaque dado a poucas pessoas, certamente sujeitos da parte de cima e central das arquibancadas, acabava por sombrear a grande massa de indivíduos que lá estava, participando do espetáculo. Embora não aparecessem nas notas das seções esportivas da imprensa, os "de baixo" (neste caso a expressão torna-se literalmente apropriada) compunham o cenário que a imagem não permite omitir.

O democrático esporte bretão permitia a participação de muitos sujeitos, à exceção daqueles que não tinham nenhuma condição de pagar pela sua apropriação. Embora fosse popular, o futebol não escapava à lógica mercantilista que dominara o novo ordenamento social. Para a distinção de público, distinção de valores. Buscava-se o lucro em todos os segmentos, o que propiciava a massificação do esporte. Se, em 1916, os ingressos custavam 
$1 \$ 000$ para as geraes e $2 \$ 000$ para as arquibancadas, em 1928 os valores sofrem alterações significativas. Para assistir a partida entre Atlético e América, em 1928, a resolução da diretoria americana fixara assim os preços: “os preços serão para as archibancadas, 3\$000; geraes, $2 \$ 000$, e cadeiras numeradas, na pista, $8 \$ 000$. As cadeiras poderão ser de hoje em diante compradas na séde social. - A Directoria” (Minas Geraes, 1928, p.11).

Além do aumento no valor dos ingressos, a principal transformação estava na criação de um novo setor: as cadeiras numeradas, com preços estipulados em $8 \$ 000$. A necessidade de distinção estava garantida, ocupando um espaço que poucos tinham condição de pagar.

\section{Futebol, consumo e identidade}

Observando as imagens das arquibancadas do recém-inaugurado estádio do América, notava-se a inserção, novamente, da publicidade da mesma marca de cerveja estampada no campo atleticano. Associar a paixão clubística à venda de produtos começava a fazer parte da maneira de agir de muitos comerciantes. Particularmente, o fato da participação feminina no ambiente esportivo da cidade ter se tornada intensa motivava reclames específicos para este público-alvo nos periódicos, como indicava a propaganda da Casa Spiller, uma loja especializada em bijuterias (fig. 06). Sobre isto, é esclarecedora a fala do historiador Leonardo Affonso de Miranda Pereira, apontando um processo similar na cidade do Rio de Janeiro, ao dizer que "resultava, deste prestígio do futebol nas altas rodas, o interesse de comerciantes e empresários que viam nele uma grande possibilidade de lucro" (PEREIRA, 200, p. 77).

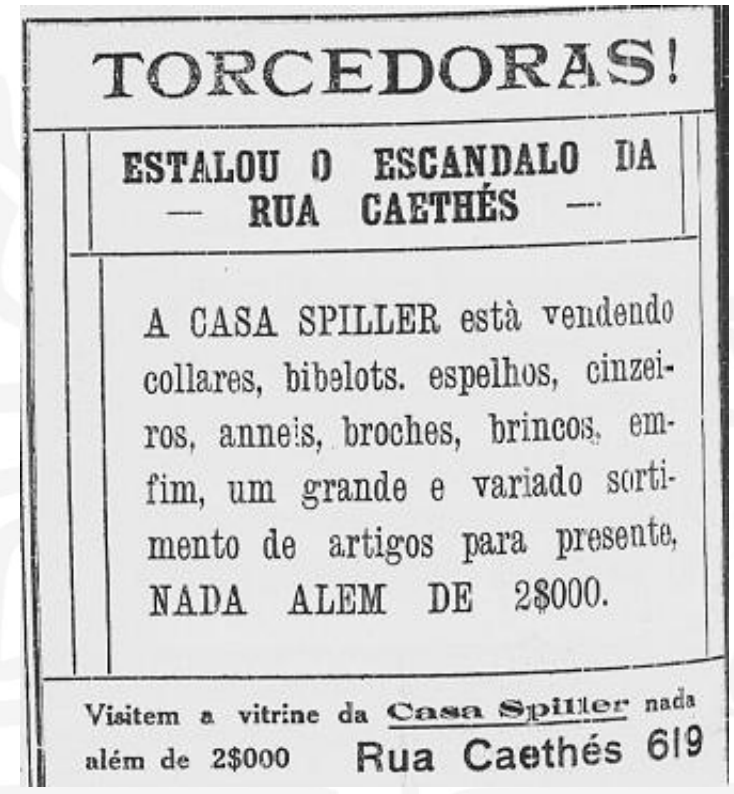

FIG. 06 - Reclame publicado na Folha Esportiva, em 19.05.1930. 
Mas a publicidade não mirava somente o público feminino. Torcedores em geral se tornavam alvo das campanhas de reclames dos periódicos locais, e indicavam a percepção dos comerciantes sobre a influência da paixão clubística na apropriação dos seus produtos. Alguns flagrantes destes reclames puderam ser captados, e estão explicitados aqui na figura 07:

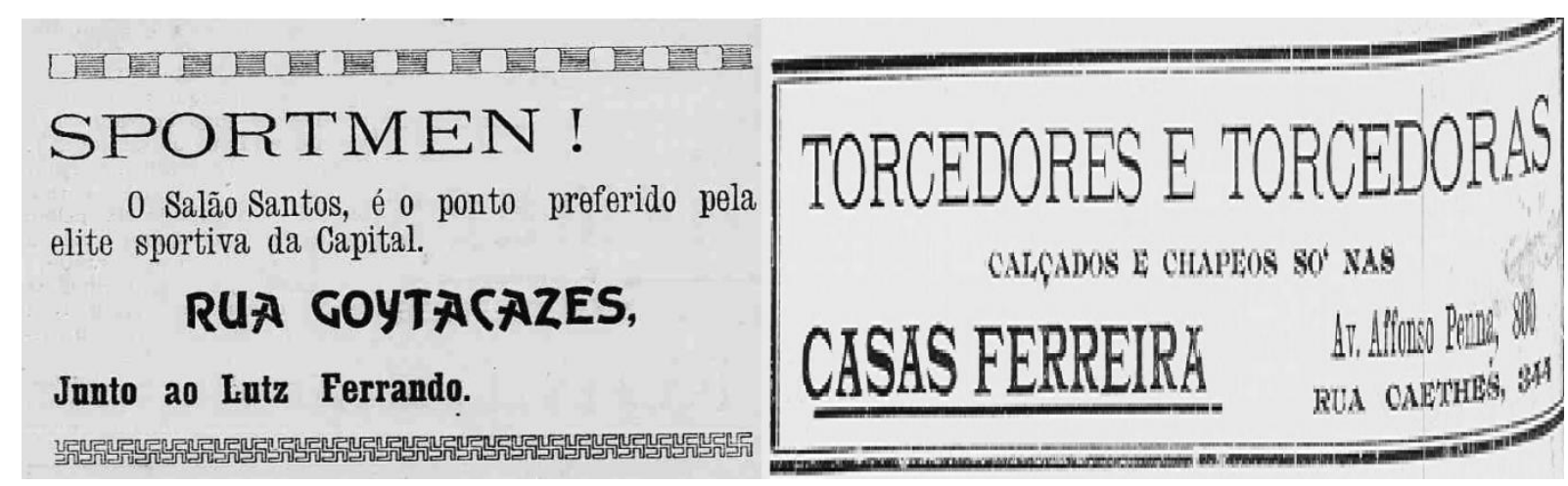

FIG. 07 - Reclames publicados no Goal, em 02.06.1930, e na Folha Esportiva, em 19.05.1930.

Para a inauguração do novo estádio americano, uma partida amistosa entre o America e o Palestra foi disputada, terminando empatada em 3 x 3. Dentre os diversos comentários tecidos sobre o evento na imprensa, destacava-se uma referência do Minas Geraes, que trazia que "[...] o que se deve destacar é a grande concorrencia de senhoras e senhorinhas da nossa sociedade, que encheram todas as archibancadas, fazendo das festas de hontem uma das mais brilhantes reuniões do anno" (Minas Geraes, 1929, p. 12).

Contudo, a mesma nota que enaltecia a presença do público feminino, apresentava também uma queixa do cronista, exatamente sobre a postura de uma dessas senhorinhas. Com o subtítulo de "Um Incidente na Archibancada", o jornalista revelava que o pertencimento e paixão clubística não se atinham a nenhuma classe, muito menos a nenhum gênero, e descrevia, indignado:

Convidados pela directoria do club, estivemos hontem no campo do America, onde os nossos redactores Jair Silva e Jairo de Almeida foram recebidos com muita gentileza pelos seus associados. [...] No intervallo do jogo, uma torcedora, que póde ser a mais bonita, mas não é ainda a mais delicada que conhecemos, passou a fazer opposição àquelles nossos queridos colegas, discordando em voz alta do acolhimento com que hontem nos distinguiram. Registrando os instantes de decepção e desapontamento que aquella moça nos reservou na esplendida festa de hontem, sob o pretexto de pertencermos ao Club Athletico Mineiro, renovamos ao commandante Oscar Paschoal e aos associados do America a homenagem da nossa admiração (Minas Geraes, 1929, p. 13). 
O incômodo da torcedora americana residia no fato do seu entendimento de que os jornalistas do Minas Geraes fossem atleticanos; e o jogo sequer era contra o Atlético. A rivalidade não perdoava tempo e espaço, assim como o torcer. Como no caso do sr. Antonio Salvo, que morava na cidade mineira de Curvelo (porta de entrada do sertão mineiro), e era torcedor do tricolor Fluminense carioca. Ao saber que o seu time iria enfrentar o América, em Belo Horizonte, o mesmo não titubeou a romper os mais de $200 \mathrm{~km}$ de distância, no intuito de assistir à partida. O fato ganhou as páginas do jornal, e sob o título "Veiu Torcer pelo Fluminense", narrava-se o feito do torcedor do time carioca:

Esteve hontem, em visita, em nossa redacção, o sr. Antonio Ernesto Salvo, que veiu de Curvello a Bello Horizonte em automovel para assistir ao grande encontro de hoje entre o America e o Fluminense. O sr. Antonio Salvo é um fervoroso tricolor e vae "torcer" hoje pelo sympathico gremio carioca (Minas Geraes, 1929, p. 13).

Nesta partida entre o America e o Fluminense, aliás, uma inusitada situação pôde ser constatada. Como o estádio americano apresentava três arquibancadas separadas, e os torcedores dos principais times da cidade compareciam aos jogos, a estrutura atendia o propósito de abrigar as torcidas, que se posicionavam de acordo com a localização das arquibancadas, o que permitia que não se misturassem. A arquibancada central seria destinada à torcida americana, e as demais divididas entre torcedores do Palestra e do Atlético. Tal fato é devidamente narrado na interessante crônica da seção esportiva do Minas Geraes:

[...] Eram quasi tres horas. E cada um ia procurando a sua archibancada. Para que os gritos tenham a approvação de gritos eguaes. Para fugir à hostilidade da torcida differente. Os palestrinos encheram a primeira archibancada. E a multidão, tendo perto o seu grande chefe Antonio Falci, contribuía com enthusiasmo para o grande barulho daquella tarde de domingo. Si algum jogador tropeçava, havia um grande silencio. E, então, com um brilho maior nos olhos, os palestrinos murmuravam, satisfeitos: - Si fosse Ninon...

$\mathrm{Na}$ archibancada do meio, o commandante Oscar Paschoal presidia a grande festa do seu club. Em torno delle, as moças americanas vibravam, gritando com enthusiasmo o nome da sua gente. [...] Elles, de certo, não ouviam. Mas, de longe, ellas continuavam a mandar-lhes conselhos carinhosos e inuteis. [...] Na terceira archibancada ficaram os athleticanos. Por toda a parte athleticanos. Reconhecidos pela naturalidade com que entravam na terceira archibancada, que é a casa do Athletico. Assim como a primeira é do Palestra e a do meio é do America (Minas Geraes, 1929, p. 14).

A derrota do America por quatro a zero frustraria a archibancada do meio, provocando sentimentos diversos nos ocupantes das outras archibancadas. De qualquer maneira, o hábito de narrar o desenrolar da partida, nos pontos de encontro social da cidade, ganhava força. Sair 
do campo e ir imediatamente passar as impressões vividas no jogo se tornara uma habitual prática. Na voz do cronista, de olhar sensível a esta postura dos torcedores, ouvia-se:

O povo começa a retirar-se, olhando para trás, com a emoção exquisita da curiosidade e da vontade de sahir primeiro. Quando Ripper faz o quarto goal, muitos já sahiram. Então, pelas ruas cheias de poeira, a noticia de mais um goal vae sendo levada longe, com a pressa que se tem de communicar, até aos desconhecidos, as coisas desagradaveis (Minas Geraes, 1929, p. 14).

O vínculo entre um clube e sua torcida podia ser notado em acontecimentos que marcavam essa relação. Acompanhar o time em jogos fora da cidade de Belo Horizonte, em excursões e caravanas esportivas, reforçava a noção de pertencimento e paixão. Torcedores apaixonados faziam questão de acompanhar as suas equipes, e tentavam estar sempre presente às partidas fora de casa. Os jogos em que os times da Capital enfrentavam o Vila Nova de Lima já não tinham apenas a torcida local. A crônica esportiva do Minas Geraes descrevia a aventura da torcida atleticana em um jogo contra o rival de Nova Lima, e mostrava o desafio de muitos que se arriscavam na viagem pelo amor ao clube alvi-negro:

Antes, muitos automoveis haviam partido. Gente horrivel, com a mania do football. Rapazes que os paes ensinaram a torcer desde creanças. Tradições de familias. O club da familia. O destino de uma descendencia inteira. Dia de festa em Nova Lima. O domingo levando homens e mulheres, que nem queriam ver a mina. Athletico! Obstinação. Vaidade. Brigas. Enthusiasmo. O Athletico!Definição: o Athletico é uma porção de pessoas de todas as classes sociaes que, aos domingos, acompanham o dr. Moura Costa. Até a Nova Lima. Bello Horizonte ficando atrás. Com as festas, as moças e os soldados. Em Nova Lima, de certo o jogo começára. Subindo morro. Descendo morro. A estrada lá em cima. O automovel que vinha parecendo que ia voltando. Que pena! Quanta gente privada de ver o Athletico! Quantos torcedores não desejariam estar alli, sob a poeira, voando para Nova Lima! Ou mesmo como nós, com aquella velocidade de camara lenta. Nova Lima apparecendo. No fundo, o campo do Villa Nova. Em redor, montanhas. A propria archibancada já era uma elevação do terreno. La dentro havia, para aquelle barulho de enthusiasmo, uma grande contribuição de Bello Horizonte. Moças torcendo pelo Athletico. E o Villa Nova tinha toda a povoação em festa. A rainha vestida de vermelho e branco. Outras moças com vestidosuniformes, cujas cores pareciam gritar "eu sou do Villa Nova". Meninas vibrantes. Estavam alli para que a victoria não sahisse de dentro daquelles morros. Gente boa de Nova Lima. Vivas e hurrahs ao Athletico. Banda de musica. Na beira do campo, uma preta toda enfeitada. A sua simplicidade encantava. E ella estava pedindo alegremente que Deus désse a victoria á sua gente do Villa Nova. Ria, perdendo o tempo. Torcendo pelo systema antigo. Barulhão na archibancada. A banda de musica sáe devagarinho. E um homem, com foguetes debaixo do braço, escapa subtilmente, levando para casa aquelle material de regosijo. Ha novo barulhão da torcida. Então a gente repara no grande numero de pessoas de Bello Horizonte. Até umas meninas da rua dos Caetés. Eram athleticanas. Ellas se haviam enganado, porque Said não jogou. Mas continuaram a torcer pelo Athletico. A gente de Nova Lima, amavel e educada, vae acceitando aquella victoria imprevista do Athletico, que o juiz José Avelino não queria. O povo grita os nomes dos jogadores do 
Athletico, fazendo um barulhão de festa no fundo dos Morros. Os automoveis sahiram numa chispada. Eram ainda cinco horas da tarde e havia sol. Meninos pretinhos esperavam, gritando "é sôpa" na beira da estrada. Para elles o Athletico fôra o vencido. E vingavam-se de não ter assistido o jogo, gritando assim á margem do caminho. Um torcedor apaixonado é que não gostou e disse, censurando: - Os inglezes precisam pôr telephone para essa gente aqui. Vejam: não sabem que nós vencemos. Olha, gury safado: dois a zero! Ouviu? Tudo poeira. Adeante, quasi não se enxergava. Automoveis levantando poeira. Bello Horizonte reapparecendo. E então, dominados pela alegria, os torcedores iam annunciando o resultado do jogo, mesmo ás pessoas que não perguntavam. A' noite, a Avenida encheu-se de athleticanos. Os palestrinos encheram o bar Excelsior. Os americanos ficaram no "Bar do Ponto". Todos commentando as tres ultimas victorias do primeiro turno do campeonato, que ante-hontem terminou (Minas Geraes, 1930, p. 10).

O texto da nota desvela comportamentos incontestáveis de paixão e pertencimento. Embora fosse considerado um time de grande torcida na Capital, o América não parecia se equiparar ao Palestra e ao Atlético quanto às demonstrações extremadas de paixão. Os noticiários reservavam a estes clubes os comentários que continham um grande apelo popular, e mais do que isto, com torcedores capazes de atos grandiosos pelo amor às cores do seu pavilhão. A abertura do Atlético a "todas as classes sociais", e a fervorosa "passione" italiana davam uma peculiar característica a estes times. Começara ali a identificação destas equipes como "clube de massa", ou ainda, "clube do povo".

$\mathrm{Na}$ disputa pela conquista de mais espaço e importância na vida social de Belo Horizonte, o Club Athletico Mineiro dava mais um passo importante, que iria marcar o ano de 1930. Se no ano anterior, a fundação do seu estádio impactaria toda a cidade, uma ousadia ainda maior ocorreria naquele ano. A inauguração do sistema de iluminação permitiria, pela primeira vez, a ocorrência de um jogo noturno. Aparentemente simples, este fato representou uma verdadeira revolução na vida esportiva da Capital, por possibilitar uma outra forma de apropriação do jogo, com horários diferenciados e a construção de uma cultura esportiva vivenciada sob uma nova ordem de tempo e espaços. Coube ao clube juizforano do Sport se bater com o Atlético, em uma festiva noite esportiva. A novidade do primeiro jogo noturno em Belo Horizonte despertava a curiosidade de uma imensa torcida, que compareceu ao estádio para ver a vitória da equipe local pelo dilatado placar de 10 x 2. Certamente, o fato não passaria em branco pela imprensa, que imprimia suas impressões sobre o acontecimento:

O PRIMEIRO NOCTURNO DE HONTEM - Gente chegando. Ambiente de circo. Banda de musica. Assovios ao estylo de vaias amarra-cahorro. Meninos vendendo amendoins. Marinetti uniformizado de jogador de golf. Marinetti discutindo com Jairo: 
- Você não joga hoje. Você não quis dormir durante o dia, como eu mandei. Jogo nocturno é differente. Quem fizer farra de dia não põe o pé na bola. [...] Confusão. Poeira subindo. Poeira dourada, á luz dos reflectores. O pessoal chispando a pé, desde o alto da Barroca á avenida Affonso Penna, [...] commemorando a primeira victoria do Athletico. A victoria que o sol não viu (Minas Geraes, 1930, p. 10).

Torcer à noite já era possível, e as torres de iluminação representavam uma conquista da modernidade a serviço do desenvolvimento do esporte. Se as torres projetavam imensos fachos de luz sobre o campo, fazendo brilhar os olhares atônitos dos torcedores, elas também permitiam, em jogos que ocorriam durante o dia, o crescimento da capacidade de público, que se debruçava sobre a estrutura metálica em busca de um ângulo original, ou de um espaço inexistente nas arquibancadas lotadas. A foto abaixo (Fig. 08) ilustra a inusitada apropriação das hastes de iluminação pela torcida do Atlético, demonstrando o seu fervor pelo time.

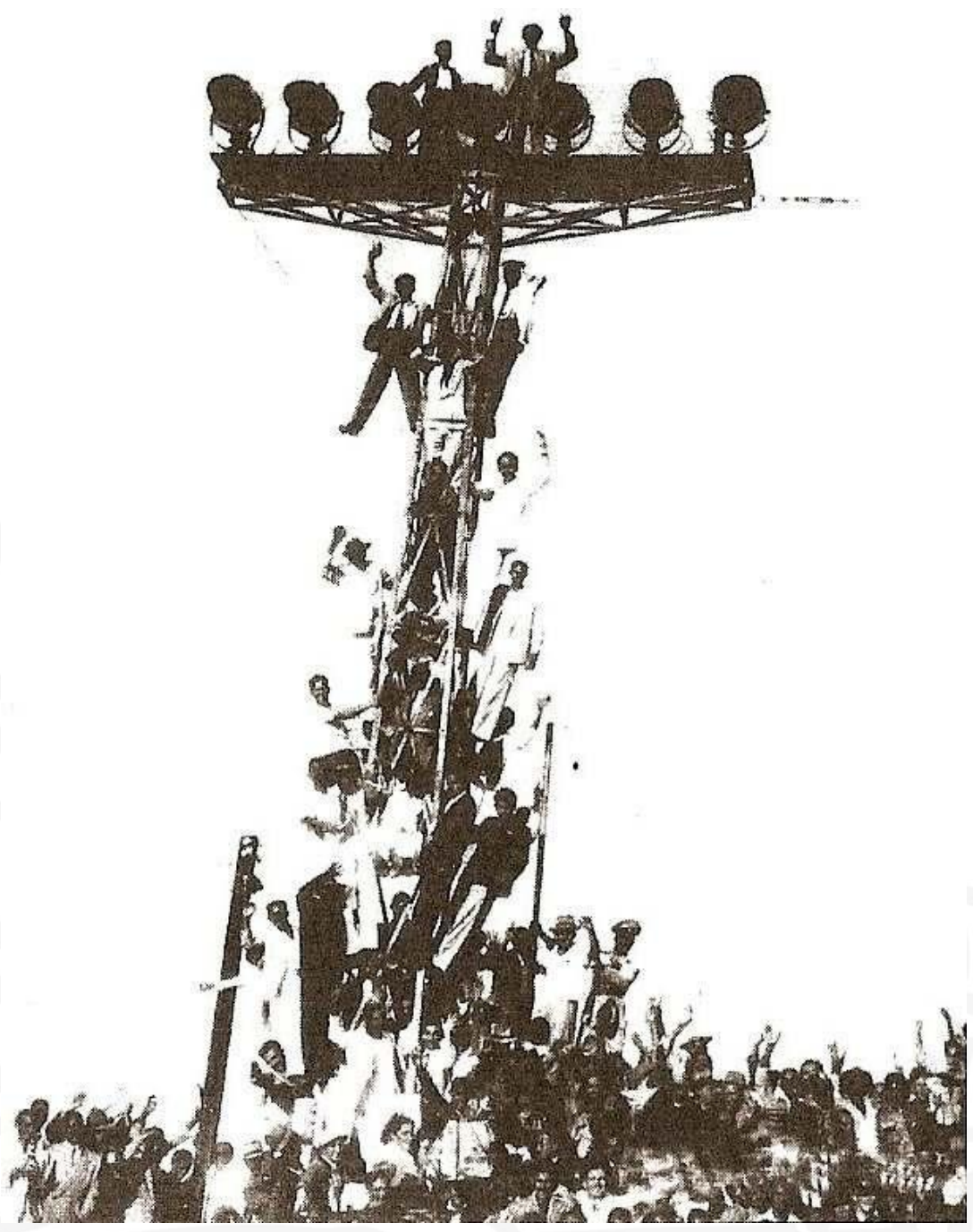

FIG. 08 - Torcedores atleticanos sobre a torre de iluminação do estádio Antônio Carlos. Fonte: Acervo do Centro Atleticano de Memória. 


\section{À guisa de conclusão}

Da assistência fidalga dos primeiros anos do futebol na Capital mineira, pouco restara nos anos finais da década de 1920. O alcance de divertimento predileto da gente horizontina projetara o torcer para uma dimensão plural, onde a diversão, o espetáculo, o consumo e a violência catártica se reuniam para compor a estrutura do pertencimento e da paixão clubística, definitivamente instituídos no seio esportivo da cidade construída com o intuito de permitir a experiência da modernidade.

A existência de uma crescente rivalidade entre os clubes acentuava o caráter de pertencimento e paixão, e estes, por sua vez, inflamavam os torcedores que acabavam se exaltando no afã de verem o seu clube vencedor. Desta forma, é possível estabelecer uma direta relação entre a existência e crescimento da violência e hostilidade com o aumento da noção de pertencimento e da paixão clubística.

Os últimos anos da década de 1920 exacerbavam a experiência espetacularizada do futebol, e refletia ocorrências singulares dos torcedores e das torcidas, como a construção de estádios grandiosos, o consumo de marcas e símbolos instituídos em concursos, a exemplo da eleição da "Rainha dos Sports", a constituição de símbolos identitários (como o hino e as mascotes), e ainda pela enorme massa de sujeitos que vivia intensamente o dia-a-dia deste esporte. Foi possível notar um desdobramento do torcer, que surge como um divertimento, se transforma em espetáculo e possibilita o desenvolvimento do consumo.

Assim, a proximidade do torcer com aspectos particularmente ligados à lógica da modernidade, como a diversão espetacularizada, o consumo e a fundação de um espaço público de catarse coletiva são as mais significativas considerações conclusivas a serem demarcadas pela investigação.

\section{Referências bibliográficas}

CARPAS. Correio Mineiro. Bello Horizonte, 18.11.1926, Jogos e Desportos, p. 3.

CORREIO MINEIRO. Bello Horizonte, 17.02.1927, Jogos e Desportos, p. 2.

CORREIO MINEIRO. Bello Horizonte, 02.04.1927, p. 1.

CORREIO MINEIRO. Bello Horizonte, 02.04.1927, Jogos e Desportos, p.2.

CORREIO MINEIRO. Bello Horizonte, 06.04.1927, Jogos e Desportos, p. 2.

CORREIO MINEIRO. Bello Horizonte, 23.04.1927, Jogos e Desportos, p. 2.

CORREIO MINEIRO. Bello Horizonte, 30.08.1927, Jogos e Desportos, p. 3.

CORREIO MINEIRO. Bello Horizonte, 31.08.1927, Jogos e Desportos, p. 3.

ELIAS, Norbert. O processo civilizador. Rio de Janeiro: Jorge Zahar, 1994, v.1.

ELIAS, Norbert; DUNNING, Eric. A Busca da Excitação. Lisboa: Difel, 1992. 
ESTADO DE MINAS. Bello Horizonte, 02.02.1930, p. 7. (Nota sem título). FOLHA ESPORTIVA. Bello Horizonte, 21.04.1930, p. 7. (Nota sem título). FOLHA ESPORTIVA. Bello Horizonte, 28.04.1930, p. 12. (Nota sem título). FOLHA ESPORTIVA. Bello Horizonte, 19.05.1930, p. 4. (Annuncios). FOLHA ESPORTIVA. Bello Horizonte, 19.05.1930, p. 12. (Annuncios). GAZETA ESPORTIVA. Bello Horizonte, 10.12.1927, Seção Desportos, p. 1. HA 32 ANNOS. Gazeta Esportiva. Bello Horizonte, 28.01.1928, p. 2. MACUMBA. Goal. Bello Horizonte, 02.06.1930, p. 3. MINAS GERAES. Bello Horizonte, 12-13.12.1927, Seção Desportos, p. 9. MINAS GERAES. Bello Horizonte, 08.09.1928, Seção Desportos, p. 11. MINAS GERAES. Bello Horizonte, 10/11.09.1928, Seção Desportos, p. 8. MINAS GERAES. Bello Horizonte, 30.05.1929, Seção Desportos, p. 10/11. MINAS GERAES. Bello Horizonte, 31.05.1929, Seção Desportos, p. 5. MINAS GERAES. Bello Horizonte, 07.09.1929, Seção Desportos, p. 24. MINAS GERAES. Bello Horizonte, 08.09.1929, Seção Desportos, p. 12. MINAS GERAES. Bello Horizonte, 09/10.09.1929, Seção Desportos, p. 14. MINAS GERAES. Bello Horizonte, 27.10.1929, Seção Desportos, p. 20. MINAS GERAES. Bello Horizonte, 04.01.1930, Seção Desportos, p. 14. MINAS GERAES. Bello Horizonte, 17/18.02.1930, Seção Desportos, p. 12. MINAS GERAES. Bello Horizonte, 02-03.06.1930, Seção Desportos, p. 11. MINAS GERAES. Bello Horizonte, 30.06/01.07.1930, Seção Desportos, p. 10. OS BONDS ESPORTIVOS. Folha Esportiva. Bello Horizonte, 21.04.1930, p. 7.

O ESTADO DE MINAS. Bello Horizonte, 11.09.1928, No Mundo dos Sports, p. 5/6. O ESTADO DE MINAS. Bello Horizonte, 25.10.1928, No Mundo dos Sports, p. 5.

PEREIRA, Leonardo Affonso de Miranda. Footballmania: uma história social do futebol no Rio de Janeiro (1902-1938). Rio de Janeiro: Nova Fronteira, 2000.

SCHOOTS. Gazeta Esportiva. Bello Horizonte, 17.12.1927, p. 2.

SEMANA ILLUSTRADA. Bello Horizonte, n. 14, 04.09.1927.

SEMANA ILLUSTRADA. Bello Horizonte, n. 29, 17.12.1927.

SEMANA ILLUSTRADA. Bello Horizonte, n. 47, 28.04.1928. 